Jørgensen, B.B., D'Hondt, S.L., and Miller, D.J. (Eds.)

Proceedings of the Ocean Drilling Program, Scientific Results Volume 201

\section{SULFUR ISOTOPE FRACTIONATION BY THE DEEP BIOSPHERE WITHIN SEDIMENTS OF THE EASTERN Equatorial Pacific and Peru Margin'}

\author{
Michael E. Böttcher, ${ }^{2,3}$ Timothy G. Ferdelman, ${ }^{2}$ Bo B. Jørgensen, ${ }^{2}$ \\ Ruth E. Blake, ${ }^{4}$ Alexander V. Surkov, ${ }^{4}$ and George E. Claypool ${ }^{5}$
}

\begin{abstract}
Fifty-seven interstitial water samples from six sites (Ocean Drilling Program Sites 1225-1229 and 1231) in the eastern equatorial Pacific Ocean and the Peru margin were analyzed for the stable sulfur isotopic composition $\left.{ }^{34} \mathrm{~S} /{ }^{32} \mathrm{~S}\right)$ of dissolved sulfate along with major and minor ions. With the exception of Site 1231, sulfate from the interstitial fluids $\left(\delta^{34} \mathrm{~S}\right.$ values as much as $89 \%$ vs. the $\mathrm{SF}_{6}$-based Vienna-Canyon Diablo troilite standard) is found at depth to be enriched in ${ }^{34} \mathrm{~S}$ with respect to modern seawater sulfate $\left(\delta^{34} S=\sim 21 \%\right.$ ), indicating that microbial sulfate reduction (MSR) took place to different extents at all investigated sites. Deeper sediments at Sites 1228 and 1229 are additionally influenced by diffusion of a sulfate-rich brine that has already undergone sulfate reduction. The intensity of MSR depends on the availability of substrate (organic matter), sedimentation conditions, and the active bacterial community structure. Formation of isotopically heavy diagenetic barite at the sulfate-methane transition zone is expected at Sites 1227 (one front), 1229 (two fronts), and probably Site 1228. At Site 1231, the constant sulfur isotopic composition of sulfate and concentrations of minor pore water ions indicate that suboxic (essentially iron and manganese oxide based) diagenesis dominates and no net MSR occurs.
\end{abstract}

${ }^{1}$ Böttcher, M.E., Ferdelman, T.G., Jørgensen, B.B., Blake, R.E., Surkov, A.V., and Claypool, G.E., 2006. Sulfur isotope fractionation by the deep biosphere within sediments of the eastern equatorial Pacific and Peru margin. In Jørgensen, B.B., D'Hondt, S.L., and Miller, D.J. (Eds.), Proc. ODP, Sci. Results, 201, 1-21 [Online]. Available from World Wide Web: $<$ http://www-odp.tamu.edu/ publications/201_SR/VOLUME/ CHAPTERS/109.PDF>. [Cited YYYYMM-DD]

${ }^{2}$ Department of Biogeochemistry, Max-Planck-Institute for Marine Microbiology, Celsiusstrasse 1, D-28359 Bremen, Germany.

Correspondence author: michael.boettcher@iowarnemuende.de

${ }^{3}$ Present address: Leibniz Institute for Baltic Seas Research, Seestrasse 15, D18119 Rostock, Germany.

${ }^{4}$ Department of Geology and Geophysics, Yale University, PO Box 208109, New Haven CT 06520-8109, USA.

58910 West Second Avenue, Lakewood CO 80226, USA.

Initial receipt: 26 July 2004

Acceptance: 2 November 2005

Web publication: 11 April 2006

Ms 201SR-109 


\section{INTRODUCTION}

Leg 201 of the Ocean Drilling Program (ODP), which took place in year 2002, was the first ocean drilling expedition completely dedicated to the study of microbial life and its impact on sediment biogeochemistry deep beneath the seafloor (D'Hondt, Jørgensen, Miller, et al., 2003). In the present study, interstitial waters from six sites (Sites 1225-1229 and Site 1231) from the eastern equatorial Pacific Ocean and the Peru margin (Fig. F1) were retrieved during Leg 201 (Table T1). The positions of the sites were chosen to be close to previously analyzed sites drilled during Deep Sea Drilling Project (DSDP) Leg 34 (Yeats, Hart, et al., 1976) and ODP Leg 112 (Suess, von Huene, et al., 1988) (Table T1). Site 1231 represents a deep-sea setting characteristic of much of the world's open ocean, and organic-poor Neogene deep-sea clays and Paleogene nannofossil ooze were recovered in the Peru Basin. Miocene to Holocene carbonate and siliceous oozes and chalk were recovered at deep-sea Sites 1225 and 1226 in the eastern equatorial Pacific. Both sites are influenced by the relatively high productivity equatorial ocean. The shallow-water Sites 1227, 1228, and 1229 are from the Peru continental margin (Fig. F1) (D'Hondt, Jørgensen, Miller, et al., 2003), and Miocene to Holocene biogenic oozes and terrigenous sediments were cored. The composite section of recovered sediments spans a time interval from the late Eocene to the Holocene (D'Hondt, Jørgensen, Miller, et al., 2003). Organic matter contents differ significantly between sites as a function of water depth and surface water productivity (Table T1). Downcore variation in the sedimentary column of the Peru margin sites (Table T1) demonstrate that sedimentation conditions changed over time. Sedimentary in situ temperatures between $1^{\circ}$ and $20^{\circ} \mathrm{C}$ (Table T1) provide environmental conditions selecting for psychrophilic and mesophilic bacteria. Whereas dissolved methane was observed in the pore waters of a number of settings, none of the investigated sites presented here contained gas hydrates.

Sulfur isotope fractionation in dissolved sulfate of pore waters is an important indicator for the occurrence of microbial sulfate reduction (MSR) in marine sediments (e.g., Hartmann and Nielsen, 1969; Jørgensen, 1979; Jørgensen et al., 2004), and stable sulfur isotope studies were among the first to show by indirect evidence that bacterial sulfate reduction takes place even in deep marine sediments (Zak et al., 1980; Brumsack et al., 1992; Böttcher et al., 1998, 2003, 2004b; Rudnicki et al., 2001). In agreement with the stable isotope evidence, microbial activity in the deep biosphere of marine sediments was found by pore water modeling (Canfield, 1991) and was later directly confirmed by microbiological and radiotracer studies (Bale et al., 1997; Parkes et al., 1994; D'Hondt, Jørgensen, Miller, et al., 2003; D'Hondt et al., 2002, 2004; Parkes et al., 2005).

In the present study, pore waters recovered during Leg 201 were analyzed for stable isotope ratios in dissolved sulfate $\left({ }^{34} \mathrm{~S} /{ }^{32} \mathrm{~S}\right)$, together with major and minor ions to identify the activity of sulfate-reducing bacteria in the sediment-pore water system. The covariation of dissolved sulfate concentrations and mass-dependent sulfur isotope discrimination is used to calculate apparent closed-system (Rayleigh) fractionation factors (Hartmann and Nielsen, 1969; Goldhaber and Kaplan, 1974; Claypool, 2004). In most sediments, however, bacterial sulfate reduction takes place under conditions that are at least partly open with respect to dissolved sulfate (e.g., Jørgensen, 1979; Jørgensen et al., 2004). There-
F1. Sampling sites, p. 13.

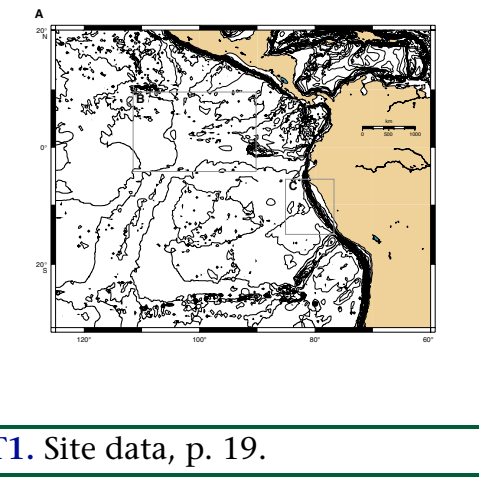


M.E. BöTTCHER ET AL.

fore, the Rayleigh-type fractionation factors are combined with a relationship recently derived by Claypool (2004) for DSDP and ODP cores to estimate for the Leg 201 sites the open system diffusional supply of dissolved sulfate. It is found that stable isotope variations indicate net microbial sulfate reduction in all sites, with the exception of the openocean deep-sea Site 1231, and that all sites are at least partially open to diffusional supply of sulfate from the bottom waters and partly from underlying brines. Sulfate supply from underlying brines is additionally found at selected sites. The oxygen isotope geochemistry of dissolved sulfate is discussed in an accompanying publication (Blake et al., this volume).

\section{METHODS}

Interstitial water samples were squeezed from whole-round cores immediately after retrieval of the cores with the standard titanium-stainless steel ODP squeezer (Manheim and Sayles, 1974). Care was taken to minimize contamination from drill fluids by the removal of the outer sediment rim. The retrieved pore waters were subsequently analyzed on board the JOIDES Resolution for concentrations of major and minor constituents, including sulfate, sulfide, and chloride, using methods described by Gieskes et al. (1991) and D'Hondt, Jørgensen, Miller, et al. (2003). Pore water samples were immediately fixed after filtration with $\mathrm{Zn}$ acetate. After removing the $\mathrm{ZnS}$ by membrane filtration $(0.45 \mu \mathrm{m})$, dissolved sulfate was precipitated quantitatively as $\mathrm{BaSO}_{4}$ by the addition of a barium chloride solution. The precipitate was washed several times with deionized water, dried at $110^{\circ} \mathrm{C}$, and baked $\left(600^{\circ} \mathrm{C}\right)$ to remove residual organic matter and water. Sulfur isotope ratios $\left({ }^{34} \mathrm{~S} /{ }^{32} \mathrm{~S}\right)$ were analyzed by combustion isotope ratio monitoring mass spectrometry (Giesemann et al., 1994; Böttcher and Schnetger, 2004). After combustion of barium sulfate to $\mathrm{SO}_{2}$ in an elemental analyzer (Eurovector), sample and calibration gas were introduced alternately in a He stream into a ThermoElectron Finnigan MAT Delta ${ }^{+}$gas mass spectrometer through a ThermoElectron Finnigan MAT Conflo II interface. Stable isotope ratios ${ }^{34} \mathrm{~S} /{ }^{32} \mathrm{~S}$ are given in the $\delta$-notation with respect to the $\mathrm{SF}_{6}$ based Vienna-Canyon Diablo troilite (V-CDT) standard (Ding et al., 1999) according to the following equation:

$$
\delta^{34} \mathrm{~S}[\% \mathrm{o}]=\left(R_{\mathrm{sample}} / R_{\mathrm{V}-\mathrm{CDT}}-1\right) \times 10^{3},
$$

where $R={ }^{34} \mathrm{~S} /{ }^{32} \mathrm{~S}$. Analytical stable isotope results are compiled in Table T2.

\section{RESULTS AND DISCUSSION}

From the downhole variation of dissolved sulfate concentrations in the interstitial waters it is evident that bacterial sulfate reduction takes place in the sediment column of all sites investigated during Leg 201, with the exception of the open-ocean deep-sea Site 1231 (Fig. F2). The high-resolution sulfate measurements carried out during Leg 201 agree remarkably well with the less-resolved data obtained during the previous Leg 112 (Fig. F2). MSR associated with the degradation of organic matter leads to the liberation of carbon dioxide, ammonium, and hy-
T2. $\delta^{34}$ S data, p. 20.

F2. Sulfate, $\delta^{34} \mathrm{~S}$ vs. depth, p. 15.

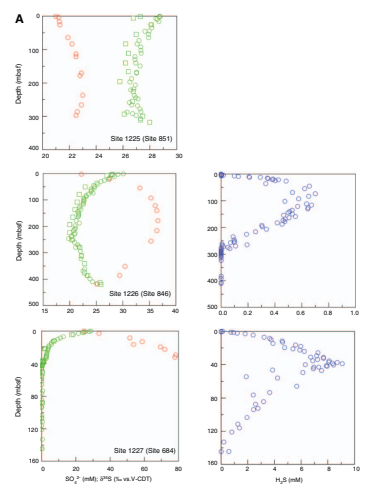


M.E. BöTTCHER ET AL.

drogen sulfide (e.g., Froelich et al., 1979) according to the overall reaction

$$
\begin{gathered}
\left(\mathrm{CH}_{2} \mathrm{O}\right)_{106}\left(\mathrm{NH}_{3}\right)_{16}\left(\mathrm{H}_{3} \mathrm{PO}_{4}\right)+53 \mathrm{SO}_{4}^{2-}+14 \mathrm{H}^{+} \rightarrow \\
106 \mathrm{H}_{2} \mathrm{O}+106 \mathrm{CO}_{2}+16 \mathrm{NH}_{4}^{+}+\mathrm{HPO}_{4}{ }^{2-}+53 \mathrm{HS}^{-}
\end{gathered}
$$

Additionally, bicarbonate and bisulfide are produced upon sulfate reduction associated with anaerobic oxidation of methane (e.g., Hoehler et al., 1994; Boetius et al., 2000). By these two microbially catalyzed processes, sulfate reduction in Leg 201 cores is associated with an increase in pore water concentrations, such as dissolved sulfide, alkalinity, and ammonium (D'Hondt, Jørgensen, Miller, et al., 2003; D'Hondt et al., 2004). The intensity of net sulfate reduction, however, differs among sampling sites depending on the availability of organic substrates for microbial activity and sediment age. Thus, very low total organic carbon (TOC) contents characterize the sediments of Site 1231, which corresponds to Leg 34 Site 321 (Table T1).

Essentially constant sulfate concentrations with depth at the openocean Site 1231 (Fig. F2) (see also Brady and Gieskes, 1976, for preliminary results from Site 321) indicate that no net sulfate reduction occurs. This is confirmed by the sulfur isotopic composition of dissolved sulfate throughout the whole sediment column (see below) and is in agreement with results from oxygen isotope analysis of dissolved sulfate (Blake et al., this volume). Some net sulfate reduction is, however, observed at the equatorial deep-sea Sites 1225 and 1226, which receive a higher flux of organic matter because of enhanced productivity (D'Hondt, Jørgensen, Miller, et al., 2003). Sulfate concentrations increase toward the bottom of the sediment column following an initial decrease to a minimum value at 200 meters below seafloor (mbsf). This increase suggests diffusion of sulfate from seawater that is flowing through underlying basaltic crust (D'Hondt, Jørgensen, Miller, et al., 2003). In contrast to the deep-sea sites, sulfate is completely exhausted at the Peru margin sites within the upper 30-40 mbsf (Fig. F2) because of higher amounts of reactive organic matter and enhanced sedimentation rates, which lead to the burial of a higher relative fraction of organic matter that may be easily consumed by microorganisms (Suess, 1980; Berner, 1980).

The experimental measurements of sulfate in the upper sulfate zone of Sites 1226-1229 gave depth-integrated gross sulfate reduction rates between 14 and $681 \mathrm{mmol} / \mathrm{m}^{2} / \mathrm{yr}$ (J. Kallmeyer and T.G. Ferdelman, pers. comm., 2004) (Table T3). These values indicate a dependence of the sulfate reduction rate on water depth, bottom water redox conditions, and, therefore, availability of organic matter. Sulfate reduction is typically less significant in the deep sea as compared to Peru margin sediments (Jørgensen, 1982; Canfield, 1991). The measured rates are lower than those typically measured on the continental margin (Jørgensen, 1982; Ferdelman et al., 1999; Fossing et al., 2000; Parkes et al., 2005; J. Kallmeyer and T.G. Ferdelman, pers. comm., 2004), but are higher than the modeled net sulfate reduction (e.g., Fossing et al., 2000; Böttcher et al., 2004b). The latter may be due to the fact that the activity of sulfate-reducing bacteria as deduced from pore water sulfate profiles tends to underestimate gross rates. Because of reoxidation of sulfide and enhanced transport processes in marine surface sediments, gross sulfate reduction rates there are typically much higher than the net rates reflected by dissolved sulfate (e.g., Fossing et al., 2000). Reduc-

T3. Rayleigh plot data, p. 21. 
M.E. BöTtCher ET AL.

tion of dissolved sulfate in the sediment is linked with the availability of metabolizable organic matter or hydrocarbons (mainly $\left.\mathrm{CH}_{4}\right)($ Berner 1980; Borowski et al., 1996; Boetius et al., 2000). The sulfate profiles at Peru margin Sites 1227, 1228, and 1229 show a convex-upward curvature (Fig. F2), which, together with the downhole variations in alkalinity and dissolved ammonium (D'Hondt, Jørgensen, Miller, et al., 2003), indicate that sulfate reduction associated with in situ microbial degradation of organic matter plays a significant role in the upper part of the sedimentary column at these sites (Borowski et al., 1996). Downcore changes in sulfate gradients are observed at Sites 1228 and 1229 and suggest a nonsteady-state contribution of sulfate reduction, probably due to changes at the beginning of the Holocene. The different sulfate gradients seem to be related to changes in sedimentation rates and corresponding changes in lithology (D'Hondt, Jørgensen, Miller, et al., 2003). In the different lithologic units of the Peru margin sites, changes in sedimentation rates (Table T1) are associated with different organic matter contents, leading to changes in substrate availabilities. High methane concentrations were not observed at Sites 1225 and 1226, due to the availability of dissolved sulfate throughout the sediment core. Therefore, no contribution from anaerobic oxidation of methane is expected at these sites.

The saline brines found at depth at Sites 1228 and 1229 are enriched in sulfate compared to modern seawater (as much as $40 \mathrm{mM}$ ) (Fig. F2) but still have isotope signatures that exceed the modern seawater value. Based on the composition of the fluids it is assumed that seawater was the source of sulfate and that microbial sulfate reduction already modified these brines in their sulfate contents and associated stable isotopic composition.

\section{Stable Sulfur Isotope Fractionation}

Microbial reduction of dissolved sulfate causes a kinetic isotope effect and an enrichment of the lighter sulfur isotope ${ }^{32} \mathrm{~S}$ in the formed hydrogen sulfide (Kaplan and Rittenberg, 1964; Chambers and Trudinger, 1979). Both open- and closed-system diagenesis lead to a corresponding accumulation of the heavy isotope $\left({ }^{34} \mathrm{~S}\right)$ in the residual sulfate (Hartmann and Nielsen, 1969; Jørgensen, 1979; Jørgensen et al., 2004). Dissolved sulfate in the modern ocean has a sulfur isotopic composition of $\sim 21 \%$ o (Böttcher et al., 2000b), which does not differ significantly from the seawater composition within the past 50 m.y. (Paytan et al., 1998). This value is closely reflected by dissolved sulfate throughout the complete pore water profile at Site 1231, indicating that no net sulfate reduction takes place. The very low activity of sulfate-reducing bacteria parallels the very low TOC contents (Table T1). Pore water constituents, however, indicate some suboxic diagenesis (D'Hondt et al., 2004; D'Hondt, Jørgensen, Miller, et al., 2003). All other investigated sites showed a downcore increase in pore water sulfate ${ }^{34} \mathrm{~S} /{ }^{32} \mathrm{~S}$ ratios, mirroring the net decrease in dissolved sulfate (Fig. F2) and indicating that the changes in sulfate concentrations are because of bacterial activity. Isotope results obtained at Site 1228 are in general agreement with previous measurements carried out on sulfate at Site 680 (Fig. F2) (G. Claypool, unpubl. data). The maximum isotope values observed in the residual dissolved sulfate decrease with increasing water depth. This trend corresponds to a decrease in the overall activity of the sulfate reducing community (Table T3). 
M.E. BÖTTCHER ET AL.

Minimum stable sulfur isotope fractionation during MSR was estimated in a first step using a (closed system) Rayleigh fractionation model (Goldhaber and Kaplan, 1974; Claypool, 2004). Measured sulfate concentrations $\left[\mathrm{SO}_{4}\right]$ and isotope ratios $(R)$ were modeled according to the following equation:

$$
\log (R)=\left(1-\alpha_{R}^{-1}\right) \log \left[\mathrm{SO}_{4}\right]+\log \left(R^{\circ}\right)-\left(1-\alpha_{R}{ }^{-1}\right) \log \left[\mathrm{SO}_{4}\right]^{\circ},
$$

where

$\circ=$ conditions at the sediment/water interface and

$\alpha_{R}=$ the fractionation factor.

In agreement with Equation 3, the pore water data gave essentially straight lines in a Rayleigh plot (Fig. F3). The resulting $\alpha_{R}$ values obtained from linear regression of the data at each site are between 1.014 and 1.040 (Table T3). These results are in the range previously calculated for marine sediments (e.g., Hartmann and Nielsen, 1969; Rudnicki et al., 2001; Böttcher et al., 2004b; Claypool, 2004). Because of the influence of transport processes (as diffusion) on pore water profiles, the actual in situ isotope fractionation factors are typically underestimated by the application of Equation 3 (Jørgensen, 1979; Goldhaber and Kaplan, 1980; Rudnicki et al., 2001; Jørgensen et al., 2004). For example, for the span of $\alpha_{R}$ values compiled in Table T3, model calculations of Rudnicki et al. (2001) for deep-ocean sediments of the Cascadia Basin gave actual isotope fractionations as much as 10\%o higher than closed-system simulations. These magnitudes of sulfur isotope discrimination obtained from pore water sulfate are within the range observed in experiments with pure cultures of mesophilic and psychrophilic sulfate-reducing bacteria, where a maximum of $-47 \%$ o has been observed (Kaplan and Rittenberg, 1964; Chambers et al., 1975; Canfield, 2001; Bolliger et al., 2001; Brüchert et al., 2001). It has additionally been found that sulfur isotope discrimination associated with anaerobic methane oxidation (Böttcher et al., 2000a) is similar to isotope effects using other electron donors (Kaplan and Rittenberg, 1964; Chambers and Trudinger, 1979; Detmers et al., 2001). Depending on the actual cellular rates of sulfate reduction (D'Hondt et al., 2002), isotope discrimination associated with this process may change (Kaplan and Rittenberg, 1964; Chambers and Trudinger, 1979; Chambers et al., 1975) and reactions from the oxidative part of the sulfur cycle may contribute to the overall isotope effects (Habicht and Canfield, 2001). Hydrogen sulfide may be reoxidized to sulfur species with intermediate oxidation states, such as elemental sulfur or thiosulfate. It has been found that the bacterial disproportionation of sulfur intermediates is associated with the production of ${ }^{32} \mathrm{~S}$ enriched sulfide (Canfield and Thamdrup, 1994; Canfield et al., 1998; Cypionka et al., 1998; Habicht et al., 1998). It should be noted, however, that in deep hypersulfidic sediments from the Australian continental margin (Wortmann et al., 2001) and in deep-sea sediments of the Cascadia Basin (Rudnicki et al., 2001), sulfur isotope discrimination even exceeding $-70 \%$ during bacterial reduction of dissolved sulfate was related to the metabolic activity of natural bacterial populations without implying further recycling by sulfur intermediates.

Claypool (2004) used results from a number of previous DSDP and ODP pore waters to derive a relationship between the openness of a sediment with respect to diffusional supply of dissolved sulfate and the cal-
F3. Rayleigh plots, p. 17.

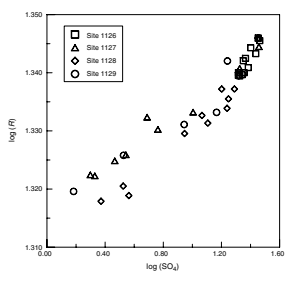


M.E. BöTtCher ET AL.

culated Rayleigh isotope fractionation factors. Results on modeled isotope discrimination from the present study (Table T3) together with recent published data from the southwest Pacific (Böttcher et al., 2004b) have been converted by the use of the relationship proposed by Claypool (2004) to derive the fraction between the diffusional flux $\left(J_{d}\right)$ and the total flux (diffusional and burial) of sulfate $\left(J_{\mathrm{d}}+J_{\mathrm{b}}\right)$. Results are compiled in Table T3 and indicate that all sediments considered here are at least partially open with respect to dissolved sulfate from the bottom waters with a minimum value for the fraction $J_{d} /\left(J_{d}+J_{b}\right)$ in Leg 201 sediments of 0.46 (Table T3). Results range up to an $82 \%$ contribution of the diffusional flux and cover the range estimated for Leg 181 sediments from the southwest Pacific (Table T3).

Sedimentary reduced sulfur as a product of dissimilatory sulfate reduction was found in the Peru margin sites and is essentially present as pyrite with minor contributions from organic sulfur (Emeis and Morse, 1990; Mossmann et al., 1990). However, sedimentary sulfur may also occur in oxidized form as biogenic barite (e.g., Paytan et al., 1998), which is used as a proxy for paleoproductivity (Paytan et al., 1996) and typically contains the isotope signature of sulfate from the water column or in surface sediments (Paytan et al., 1998). In the zone of complete sulfate depletion, biogenic barite may redissolve and barium may diffuse upward in the sediment column toward the lower part of the sulfate zone. Because of the low solubility of barium sulfate, barite may precipitate at a "diagenetic front" (Brumsack et al., 1992; Torres et al., 1996; Böttcher et al., 2003; D'Hondt, Jørgensen, Miller, et al., 2003). Based on the pore water profiles observed in the sediments recovered during Leg 201 (Fig. F2) (D'Hondt, Jørgensen, Miller, et al., 2003), the dissolution of biogenic barite and the development of a diagenetic barite front can be inferred at Sites 1227, 1229, and probably 1228 (Fig. F2). The position of the barite front is expected to be at 30-40, 40, and $30 \mathrm{mbsf}$ at Sites 1227, 1228, and 1229, respectively. The occurrence of a sulfate-rich brine at depth at Sites 1228 and 1229 can lead to the parallel development of a second, deeper-seated barite front at $\sim 50$ (Site 1228 ) and $~ 90$ (Site 1229) mbsf. Based on the present isotopic composition of dissolved sulfate $(\sim 80 \% 0-90 \%$ V-CDT), the diagenetic barite should be highly enriched in ${ }^{34} \mathrm{~S}$ with respect to modern biogenic barite (Paytan et al., 1998) and Pacific Ocean water sulfate (Longinelli, 1989; Böttcher et al., 2000a, 2004b). As introduced by Böttcher et al. (2004a), the magnitude of heavy (sulfur and oxygen) stable isotope enrichments in diagenetic barite may serve as an indicator for the steepness of paleosulfate gradients during the development of barite fronts. Investigations in cooperation with Glen Snyder have been initiated to look at the stable sulfur isotopic composition of barite in the diagenetic fronts that developed in sulfate-depleted Leg 201 sediments. At Sites 1225, 1226, and 1231, interstitial water sulfate does not decrease to an extent that biogenic barite remobilization and formation of diagenetic barite is expected.

\section{CONCLUSIONS}

The analysis of stable sulfur isotope ratios in dissolved sulfate from interstitial waters recovered from sediments of the eastern equatorial Pacific and the Peru margin demonstrate that net dissimilatory reduction of sulfate by a deep biosphere takes place to different extents at all investigated sites, except for the open-ocean deep-sea Site 1231. Maxi- 
M.E. BöTTCHER ET AL.

mum $\delta^{34} S$ values are also consistent with both modeled and measured sulfate reduction rates, which show decreasing rates with increases in water depth. Observed sulfur isotope discrimination indicates different degrees of openness of the sediment column with respect to dissolved sulfate. The dominant processes controlling sulfur isotope fractionation in dissolved sulfate are dissimilatory bacterial sulfate reduction and mixing with deep sulfate-rich brines (Fig. F4). Sulfate in these deep brines seems to be derived from seawater that was evaporated and already subjected to microbial sulfate reduction.

Therefore, the results from Leg 201 show that sulfur isotope fractionation in interstitial water sulfate is an extremely powerful tool in the evaluation of sinks, sources, and especially microbiological transformation reactions upon sulfur diagenesis by the deep biosphere in different types of marine sediments.

\section{ACKNOWLEDGMENTS}

We thank the scientific and technical crew of Leg 201 for support during sampling. M.E. Böttcher wishes to thank E. Clapton, P. Gabriel, and J. Stone for their musical influence on the accoustic atmosphere during manuscript preparation. This research used samples and/or data provided by the Ocean Drilling Program (ODP). ODP is sponsored by the U.S. National Science Foundation (NSF) and participating countries under management of Joint Oceanographic Institutions (JOI), Inc. Research was funded by Max Planck Society, Germany. The authors acknowledge the constructive review comments by Tim W. Lyons.
F4. Sulfate vs. $\delta^{34}$, , p. 18.

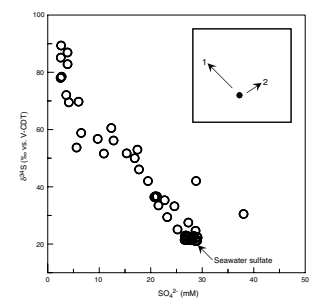




\section{REFERENCES}

Bale, S.J., Goodman, K., Rochelle, P.A., Marchesi, J.R., Fry, J.C., Weightman, A.J., and Parkes, R.J., 1997. Desulfovibrio profundus sp. nov., a novel barophilic sulfate-reducing bacterium from deep sediment layers in the Japan Sea. Int. J. Syst. Bacteriol., 47:515-521.

Berner, R.A., 1980. Early Diagenesis: A Theoretical Approach: Princeton, NJ (Princeton Univ. Press).

Boetius, A., Ravenschlag, K., Schubert, C.J., Rickert, D., Widdel, F., Gieseke, A., Amann, R., Jørgensen, B.B., Witte, U., and Pfannkuche, O., 2000. A marine microbial consortium apparently mediating the anaerobic oxidation of methane. Nature (London, U. K.), 407:623-626. doi:10.1038/35036572

Bolliger, C., Schroth, M.H., Bernasconi, S.M., Kleikemper, J., and Zeyer, J., 2001. Sulfur isotope fractionation during microbial sulphate reduction by toluene-degrading bacteria. Geochim. Cosmochim. Acta, 65(19):3289-3298. doi:10.1016/S00167037(01)00671-8

Borowski, W.S., Paull, C.K., and Ussler, W., III, 1996. Marine pore-water sulfate profiles indicate in situ methane flux from underlying gas hydrate. Geology, 24(7):655658. doi:10.1130/0091-7613(1996)024<0655:MPWSPI >2.3.CO;2

Böttcher, M.E., Boetius, A., and Rickert, D., 2000a. Sulfur isotope biogeochemistry related to intense microbial sulfate reduction and anaerobic methane oxidation in marine deep-sea sediments (Hydrate Ridge). J. Conf. Abstr., 5:230.

Böttcher, M.E., Brumsack, H.-J., and de Lange, G.J., 1998. Sulfate reduction and related stable isotope $\left({ }^{34} \mathrm{~S},{ }^{18} \mathrm{O}\right)$ variations in interstitial waters from the eastern Mediterranean. In Robertson, A.H.F., Emeis, K.-C., Richter, C., and Camerlenghi, A. (Eds.), Proc. ODP, Sci. Results, 160: College Station, TX (Ocean Drilling Program), 365-373. [PDF]

Böttcher, M.E., Brumsack, H.-J., Schipper, A., Arndt, S., and Hetzel, A., 2004a. Authigenic sulfur phases as recorders for black shale-triggered anaerobic oxidation of methane (ODP Leg 207). Eur. J. Mineral., 16:18.

Böttcher, M.E., Khim, B.-K., Suzuki, A., Gehre, M., Wortmann, U.G., and Brumsack, H.-J., 2004b. Microbial sulfate reduction in deep sediments of the southwest Pacific (ODP Leg 181: Sites 1119-1125): evidence from stable sulfur isotope fractionation and pore water modeling. Mar. Geol., 205(1-4):249-260. doi:10.1016/S00253227(04)00026-X

Böttcher, M.E., Rinna, J., Warning, B., Wehausen, R., Howell, M.W., Schnetger, B., Stein, R., Brumsack, H.-J., and Rullkötter, J., 2003. Geochemistry of sediments from the connection between the western and eastern Mediterranean Sea (Strait of Sicily, ODP Site 963). Palaeogeogr., Palaeoclimatol., Palaeoecol., 190:165-194. doi:10.1016/S0031-0182(02)00604-1

Böttcher, M.E., Schale, H., Schnetger, B., Wallmann, K., and Brumsack, H.-J., 2000b. Stable sulfur isotopes indicate net sulfate reduction in near-surface sediments of the deep Arabian Sea. Deep-Sea Res., Part II, 47:2769-2783.

Böttcher, M.E., and Schnetger, B., 2004. Direct measurement of the content and isotopic composition of sulfur in black shales by means of combustion-isotope-ratiomonitoring mass spectrometry (C-irmMS). In de Groot, P. (Ed.), Handbook of Stable Isotope Analytical Techniques: Amsterdam (Elsevier), 597-603.

Brady, S., and Gieskes, J.M., 1976. Interstitial water studies, Leg 34. In Yeats, R.S., Hart, S.R., et al., Init. Repts. DSDP, 34: Washington (U.S. Govt. Printing Office), 625-628.

Brüchert, V., Knoblauch, C., and Jørgensen, B.B., 2001. Controls on stable sulfur isotope fractionation during bacterial sulfate reduction in Arctic sediments. Geochim. Cosmochim. Acta, 65(5):763-776. doi:10.1016/S0016-7037(00)00557-3

Brumsack, H.-J., Zuleger, E., Gohn, E., and Murray, R.W., 1992. Stable and radiogenic isotopes in pore waters from Leg 127, Japan Sea. In Pisciotto, K.A., Ingle, J.C., Jr., 
von Breymann, M.T., Barron, J., et al., Proc. ODP, Sci. Results, 127/128 (Pt. 1): College Station, TX (Ocean Drilling Program), 635-650.

Cameron, D.H., 1976. Carbon and carbonate analyses, Leg 34. In Yeats, R.S., Hart, S.R., et al., Init. Repts. DSDP, 34: Washington (U.S. Govt. Printing Office), 601-602.

Canfield, D.E., 1991. Sulfate reduction in deep-sea sediments. Am. J. Sci., 291:177188.

Canfield, D.E., 2001. Isotope fractionation by natural populations of sulfate-reducing bacteria. Geochim. Cosmochim. Acta, 65(7):1117-1124. doi:10.1016/S00167037(00)00584-6

Canfield, D.E., and Thamdrup, B., 1994. The production of ${ }^{34}$ S-depleted sulfide during bacterial disproportionation of elemental sulfur. Science, 266:1973-1975.

Canfield, D.E., Thamdrup, B., and Fleischer, S., 1998. Isotope fractionation and sulfur metabolism by pure and enrichment cultures of elemental sulfur-disproportionating bacteria. Limnol. Oceanogr., 43:235-264.

Chambers, L.A., and Trudinger, P.A., 1979. Microbiological fractionation of stable sulfur isotopes: a review and critique. Geomicrobiol. J., 1(3):249-293.

Chambers, L.A., Trudinger, P.A., Smith, J.W., and Burns, M.S., 1975. Fractionation of sulfur isotopes by continuous cultures of Desulfovibrio desulfuricans. Can. J. Microbiol., 21:1602-1609.

Claypool, G.E., 2004. Ventilation of marine sediments indicated by depth profiles of porewater sulfate and $\delta^{34} \mathrm{~S}$. In Hill, R.J., Leventhal, J., Aizenshtat, Z., Beadecker, M.J., Claypool, G.E., Eganhouse, R., Goldhaber, M.B., and Peters, K. (Eds.), Geochemical Investigations in Earth and Space Science. Spec. Publ.-Geochem. Soc., 9:59-65.

Cypionka, H., Smock, A., and Böttcher, M.E., 1998. A combined pathway of sulfur compound disproportionation in Desulfovibrio desulfuricans. FEMS Microbiol. Lett., 166(2):181-186. doi:10.1016/S0378-1097(98)00330-9

D’Hondt, S.L., Jørgensen, B.B., Miller, D.J., et al., 2003. Proc. ODP, Init. Repts., 201 [CD-ROM]. Available from: Ocean Drilling Program, Texas A\&M University, College Station TX 77845-9547, USA. [HTML]

D’Hondt S., Jørgensen, B.B., Miller, D.J., Batzke, A., Blake, R., Cragg, B.A., Cypionka, H., Dickens, G.R., Ferdelman, T., Hinrichs, K.U., Holm, N.G., Mitterer, R., Spivack, A., Wang, G.Z., Bekins, B., Engelen, B., Ford, K., Gettemy, G., Rutherford, S.D., Sass, H., Skilbeck, C.G., Aiello, I.W., Guerin, G., House, C.H., Inagaki, F., Meister, P., Naehr, T., Niitsuma, S., Parkes, R.J., Schippers, A., Smith, D.C., Teske, A., Wiegel, J., Padilla, C.N., and Acosta, J.L.S., 2004. Distributions of microbial activities in deep subseafloor sediments. Science, 306:2216-2221. doi:10.1126/science.1101155

D'Hondt, S., Rutherford, S., and Spivack., A.J., 2002. Metabolic activity of the subsurface biosphere in deep-sea sediments. Science, 295:2067-2070. doi:10.1126/science.1064878

Detmers, J., Bruechert, V., Habicht, K., and Küver, J., 2001. Diversity of sulfur isotope fractionation by sulfate-reducing procaryotes. Appl. Environ. Microbiol., 76:888894.

Ding, T., Bai, R., Li, Y., Wan, D., Zou, X., and Zhang, Q., 1999. Determination of the absolute ${ }^{32} \mathrm{~S} /{ }^{34} \mathrm{~S}$ ratio of IAEA-S-1 reference material and V-CDT sulfur isotope standard. Sci. China, Ser. D: Earth Sci., 42:45-51.

Emeis, K.-C., and Morse, J.W., 1990. Organic carbon, reduced sulfur, and iron relationships in sediments of the Peru margin, Sites 680 and 688. In Suess, E., von Huene, R., et al., Proc. ODP, Sci. Results, 112: College Station, TX (Ocean Drilling Program), 441-453.

Ferdelman, T., Fossing, H., Neumann, K., and Schulz, H.D., 1999. Sulfate reduction in surface sediments of the southwest Atlantic continental margin between $15^{\circ} 38^{\prime} \mathrm{S}$ and $27^{\circ} 57^{\prime} \mathrm{S}$ (Angola and Namibia). Limnol. Oceanogr., 44:650-661.

Fossing, H., Ferdelman, T.G., and Berg, P., 2000. Sulfate reduction and methane oxidation in continental margin sediments influenced by irrigation (south-east Atlan- 
tic off Namibia). Geochim. Cosmochim. Acta, 64:897-910. doi:10.1016/S00167037(99)00349-X

Froelich, P.N., Klinkhammer, G.P., Bender, M.L., Luedtke, N.A., Heath, G.R., Cullen, D., Dauphin, P., Hammond, D., Hartman, B., and Maynard, V., 1979. Early oxidation of organic matter in pelagic sediments of the eastern equatorial Atlantic: suboxic diagenesis. Geochim. Cosmochim. Acta, 43(7):1075-1090. doi:10.1016/00167037(79)90095-4

Giesemann, A., Jäger, H.-J., Norman, A.L., Krouse, H.R., and Brand, W.A., 1994. Online sulphur isotope determination using an elemental analyzer coupled to a mass spectrometer. Anal. Chem., 66:2816-2819.

Gieskes, J.M., Gamo, T., and Brumsack, H., 1991. Chemical methods for interstitial water analysis aboard JOIDES Resolution. ODP Tech. Note, 15 [Online]. Available from World Wide Web: <http://www-odp.tamu.edu/publications/tnotes/tn15/ f_chem1.htm>. [Cited 2005-11-02]

Goldhaber, M.B., and Kaplan, I.R., 1974. The sulfur cycle. In Goldberg, E.D. (Ed.), The Sea (Vol. 5): Marine Chemistry: The Sedimentary Cycle: New York (Wiley-Interscience), 569-655.

Goldhaber, M.B., and Kaplan, I.R., 1980. Mechanisms of sulfur incorporation and isotope fractionation during early diagenesis in sediments of the Gulf of California. Mar. Chem., 9:95-143. doi:10.1016/0304-4203(80)90063-8

Habicht, K.S., and Canfield, D.E., 2001. Isotope fractionation by sulfate-reducing natural populations and the isotopic composition of sulfide in marine sediments. Geology, 29:555-558. doi:10.1130/0091-7613(2001)029<0555:IFBSRN>2.0.CO;2

Habicht, K.S., Canfield, D.E., and Rethmeier, J., 1998. Sulfur isotope fractionation during bacterial reduction and disproportionation of thiosulfate and sulfite. Geochim. Cosmochim. Acta, 62:2585-2595. doi:10.1016/S0016-7037(98)00167-7

Hartmann, M., and Nielsen, H., 1969. $\delta^{34}$ S-Werte in rezenten Meeressedimenten und ihre Deutung am Beispiel einiger Sedimentprofile aus der westlichen Ostsee. Geol. Rundsch., 58:621-655.

Hoehler T.M., Alperin, M.J., and Martens, C.S., 1994. Field and laboratory studies of methane oxidation in an anoxic sediment-evidence for methanogen-sulfate reducer consortium. Global Biogeochem. Cycles, 8:451-463.

Jørgensen, B.B., 1979. A theoretical model of the stable sulfur isotope distribution in marine sediments. Geochim. Cosmochim. Acta, 43:363-374. doi:10.1016/00167037(79)90201-1

Jørgensen, B.B., 1982. Mineralization of organic matter in the seabed-the role of sulphate reduction. Nature (London, U. K.), 296:643-645. doi:10.1038/296643a0

Jørgensen, B.B., Böttcher, M.E., Lüschen, H., Neretin, L.N., and Volkov, I.I., 2004. Anaerobic methane oxidation and a deep $\mathrm{H}_{2} \mathrm{~S}$ sink generate isotopically heavy sulfides in Black Sea sediments. Geochim. Cosmochim. Acta, 68:2095-2118. doi:10.1016/j.gca.2003.07.017

Kaplan, I.R., and Rittenberg, S.C., 1964. Microbiological fractionation of sulfur isotopes. J. Gen. Microbiol., 34:195-212.

Longinelli, A., 1989. Oxygen-18 and sulphur-34 in dissolved oceanic sulphate and phosphate. In Fritz, P., and Fontes, J.C. (Eds.), The Marine Environment. Handb. Environ. Isot. Geochem., 3:219-255.

Manheim, F.T., and Sayles, F.L., 1974. Composition and origin of interstitial waters of marine sediments, based on deep sea drill cores. In Goldberg, E.D. (Ed.), The Sea (Vol. 5): Marine Chemistry: The Sedimentary Cycle: New York (Wiley), 527-568.

Mossmann, J.-R., Aplin, A.C., Curtis, C.D., and Coleman, M.L., 1990. Sulfur geochemistry at Sites 680 and 686 on the Peru margin. In Suess, E., von Huene, R., et al., Proc. ODP, Sci. Results, 112: College Station, TX (Ocean Drilling Program), 455-464.

Parkes, R.J., Cragg, B.A., Bale, S.J., Getliff, J.M., Goodman, K., Rochelle, P.A., Fry, J.C., Weightman, A.J., and Harvey, S.M., 1994. Deep bacterial biosphere in Pacific Ocean sediments. Nature (London, U. K.), 371:410-413. doi:10.1038/371410a0 
M.E. BÖTTCHER ET AL.

Parkes, R.J., Webster, G., Cragg, B.A., Weightman, A.J., Newberry, C.J., Ferdelman, T.G., Kallmeyer, J., Jørgensen, B.B., Aiello, I.W., and Fry, J.C., 2005. Deep sub-seafloor prokaryotes stimulated at interfaces over geological time. Nature (London, $U$. K.), 436:390-394. doi:10.1038/nature03796

Paytan, A., Kastner, M., Campbell, D., and Thiemens, M.H., 1998. Sulfur isotopic composition of Cenozoic seawater sulfate. Science, 282:1459-1462. doi:10.1126/ science.282.5393.1459

Paytan, A., Kastner, M., and Chavez, F., 1996. Glacial to interglacial fluctuations in productivity in the equatorial Pacific as indicated by marine barite. Science, 274:1355-1357. doi:10.1126/science.274.5291.1355

Rudnicki, M.D., Elderfield, H., and Spiro, B., 2001. Fractionation of sulfur isotopes during bacterial sulfate reduction in deep ocean sediments at elevated temperatures. Geochim. Cosmochim. Acta, 65:777-789. doi:10.1016/S0016-7037(00)00579-2

Suess, E., 1980. Particulate organic carbon flux in the oceans: surface productivity and oxygen utilization. Nature (London, U. K.), 288:260-263. doi:10.1038/ $288260 \mathrm{aO}$

Suess, E., von Huene, R., et al., 1988. Proc. ODP, Init. Repts., 112: College Station, TX (Ocean Drilling Program).

Torres, M.E., Brumsack, H.J., Bohrmann, G., and Emeis, K.C., 1996. Barite fronts in continental margin sediments: a new look at barium remobilization in the zone of sulfate reduction and formation of heavy barites in diagenetic fronts. Chem. Geol., 127:125-139. doi:10.1016/0009-2541(95)00090-9

von Breymann, M.T., Emeis, K.-C., and Camerlenghi, A., 1990. Geochemistry of sediments from the Peru upwelling area: results from Sites 680, 682, 685, and 688. In Suess, E., von Huene, R., et al., Proc. ODP, Sci. Results, 112: College Station, TX (Ocean Drilling Program), 491-503.

Wortmann, U.G., Bernasconi, S.M., and Böttcher, M.E., 2001. Hypersulfidic deep biosphere indicates extreme sulfur isotope fractionation during single-step microbial sulfate reduction. Geology, 29:647-650. doi:10.1130/0091-7613(2001)029<0647:HDBIES>2.0.CO;2

Yeats, R.S., Hart, S.R., et al., 1976. Init. Repts DSDP, 34: Washington (U.S. Govt. Printing Office).

Zak, I., Sakai, H., and Kaplan, I.R., 1980. Factors controlling the ${ }^{18} \mathrm{O} /{ }^{16} \mathrm{O}$ and ${ }^{34} \mathrm{~S} /{ }^{32} \mathrm{~S}$ isotope ratios of ocean sulfates, evaporites and interstitial sulfates from modern deep sea sediments. In Goldberg, E.D., Horibe, Y., and Saruhashi, K. (Eds.), Isotope Marine Chemistry: Tokyo (Rokakuho), 339-373. 
M.E. BötTCHER ET AL.

SULFUR ISOTOPE FRACTIONATION

Figure F1. A. Sampling sites of Leg 201 compared to previous sites drilled during DSDP Leg 34 and ODP Leg 112 (from D’Hondt, Jørgensen, Miller, et al., 2003). (Continued on next page.)

A

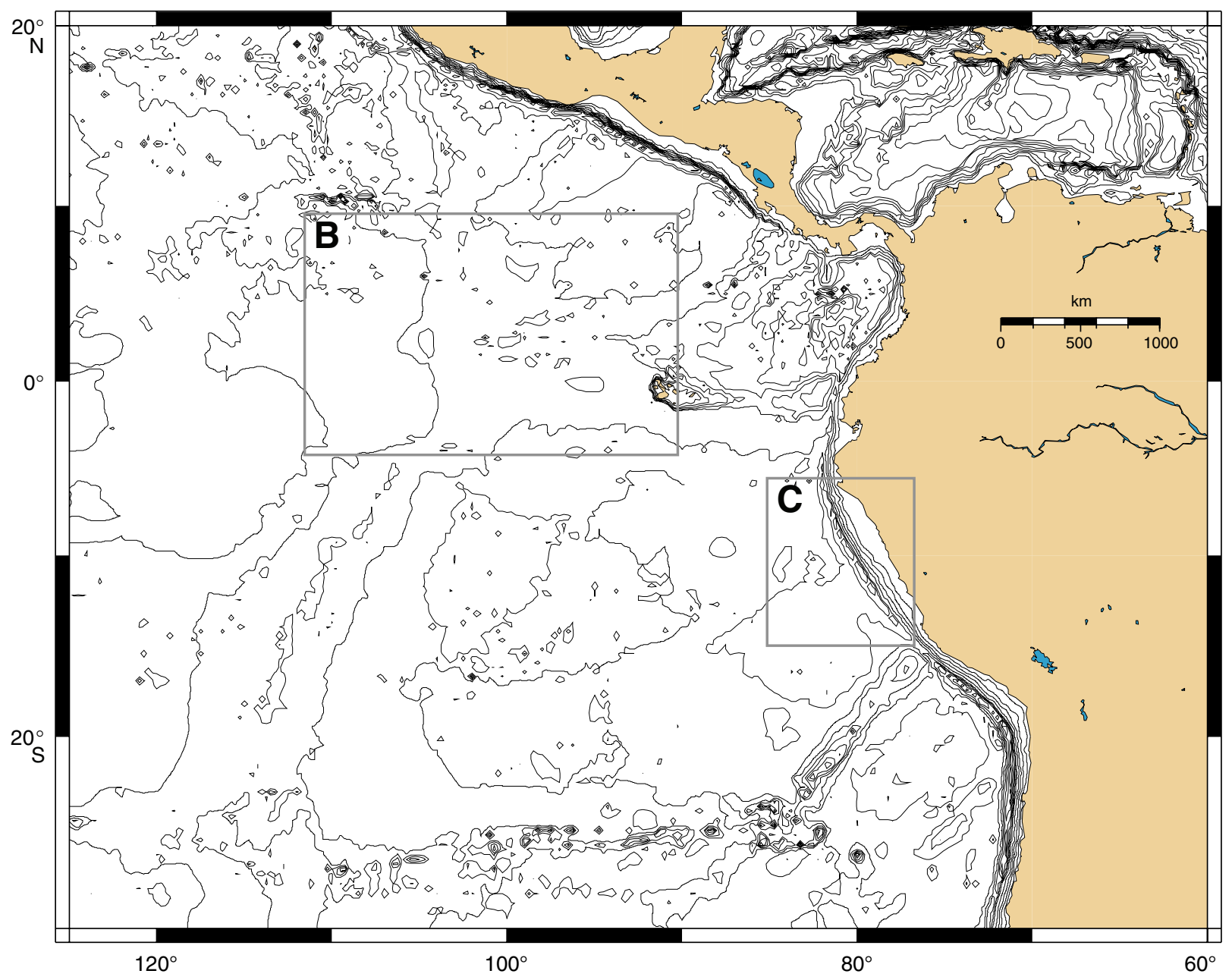


M.E. BötTCHER ET AL.

SULFUR ISOTOPE FRACTIONATION

Figure F1 (continued). B. Location of Sites 1225 and 1226. C. Location of Sites 1227 through 1231.
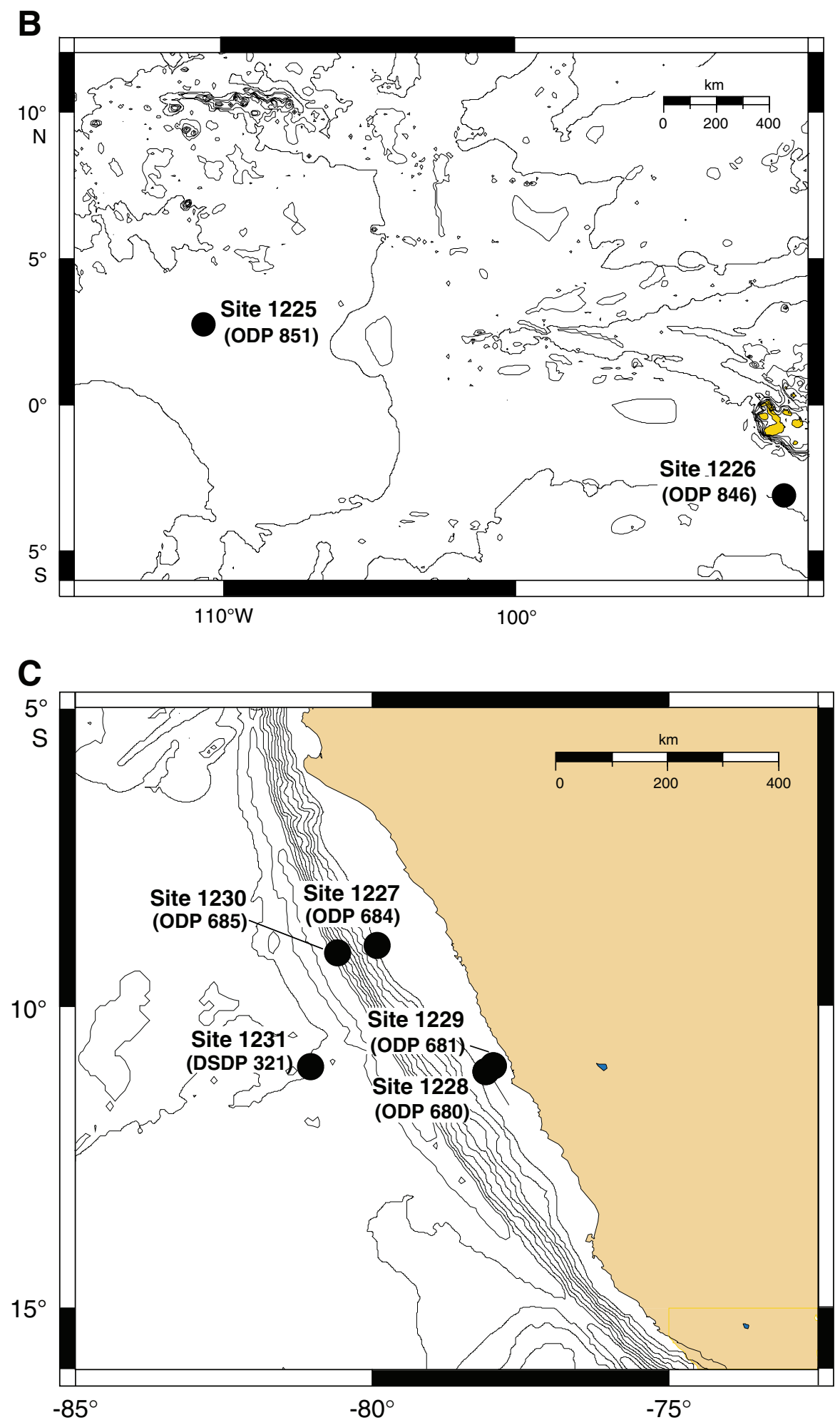
M.E. BöTTCHER ET AL.

SULFUR ISOTOPE FRACTIONATION

Figure F2. Leg 201 pore water sulfate concentrations (green circles) and $\delta^{34} S$ values (red circles) vs. depth. Green squares indicate sulfate concentrations measured in pore waters from previous sites drilled on almost identical positions during DSDP Leg 34 and ODP Leg 112 (Yeats, Hart, et al., 1976; Suess, von Huene, et al., 1988). $\mathrm{H}_{2} \mathrm{~S}$ data are total dissolved sulfide data and taken from $\mathrm{D}^{\prime}$ Hondt, Jørgensen, Miller, et al. (2003). A. Sites 1225, 1226, and 1227. Sulfide was below detection limit in Site 1225 pore water. V-CDT = ViennaCanyon Diablo troilite. (Continued on next page.)
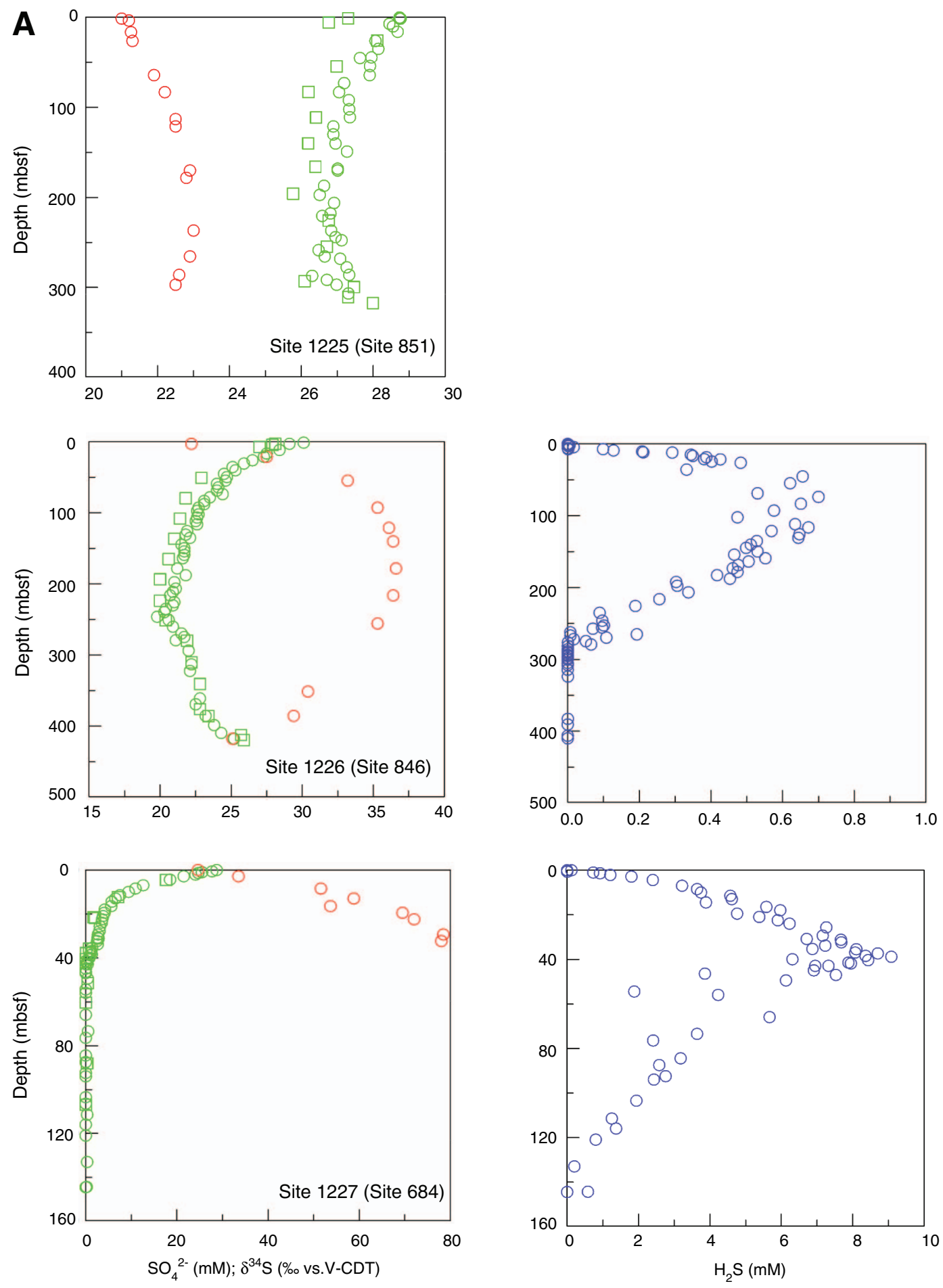
M.E. BöTTCHER ET AL.

SULFUR ISOTOPE FRACTIONATION

Figure F2 (continued). B. Sites 1228, 1229, and 1231. Red squares indicate the sulfur isotopic composition of dissolved sulfate measured in pore water at Site 680 (G. Claypool, unpubl. data). Sulfide was below detection limit in Site 1231 pore water. V-CDT = Vienna-Canyon Diablo troilite.
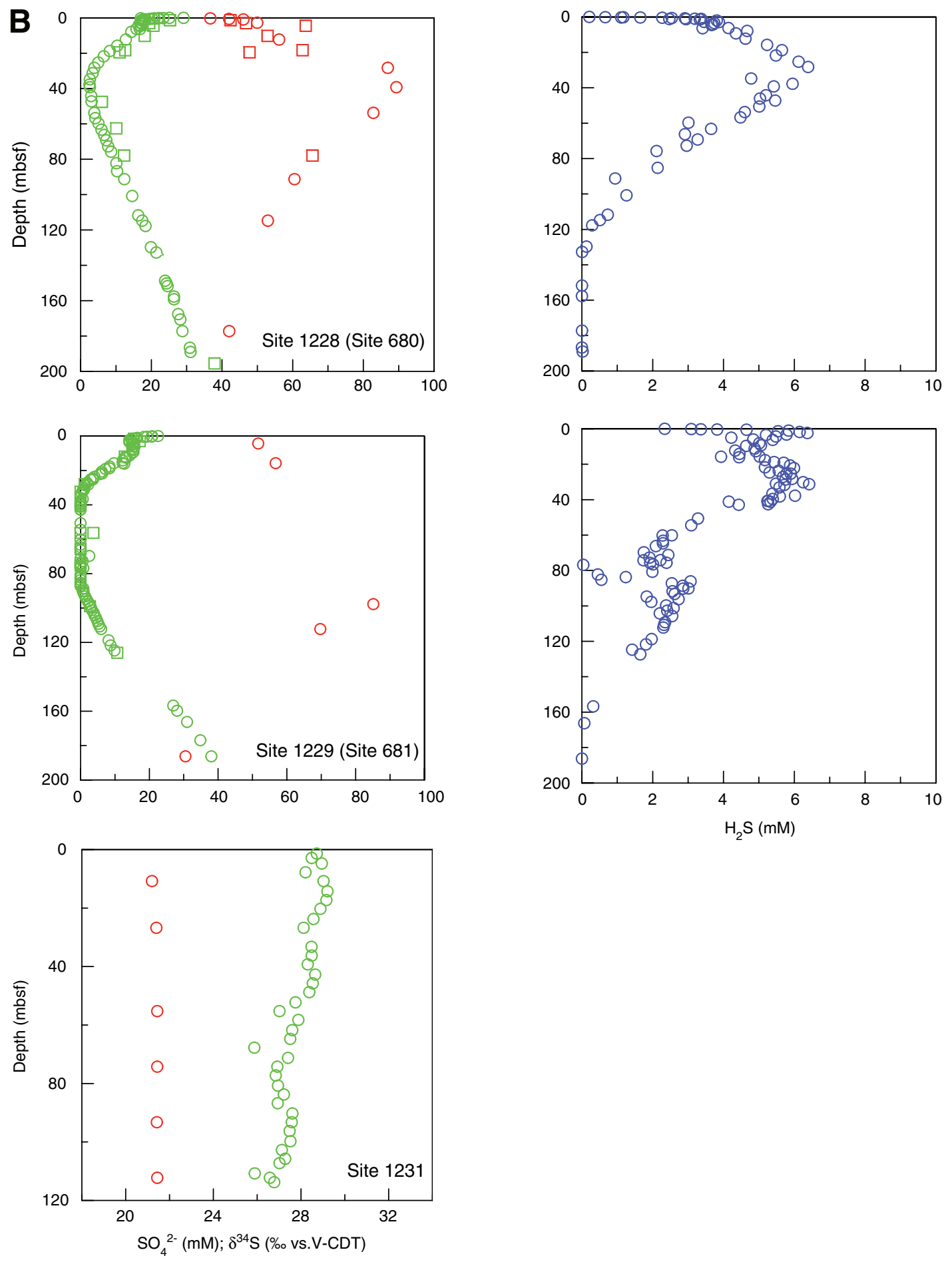
M.E. BöTTCHER ET AL.

SULFUR ISOTOPE FRACTIONATION

Figure F3. Rayleigh plots for pore water at Leg 201 sites (except Sites 1225 and 1231). Isotope ratios $(R)$ were calculated using the measured isotope data based on the isotope ratio for the V-CDT standard (Ding et al., 1999). Based on chloride concentrations, all sulfate concentrations are normalized to the respective shallowest pore water sample of a given profile. Linear regression coefficients $\left(r^{2}\right)$ are $0.83,0.97,0.94$, and 0.90 for Sites 1226, 1227, 1228, and 1229, respectively.

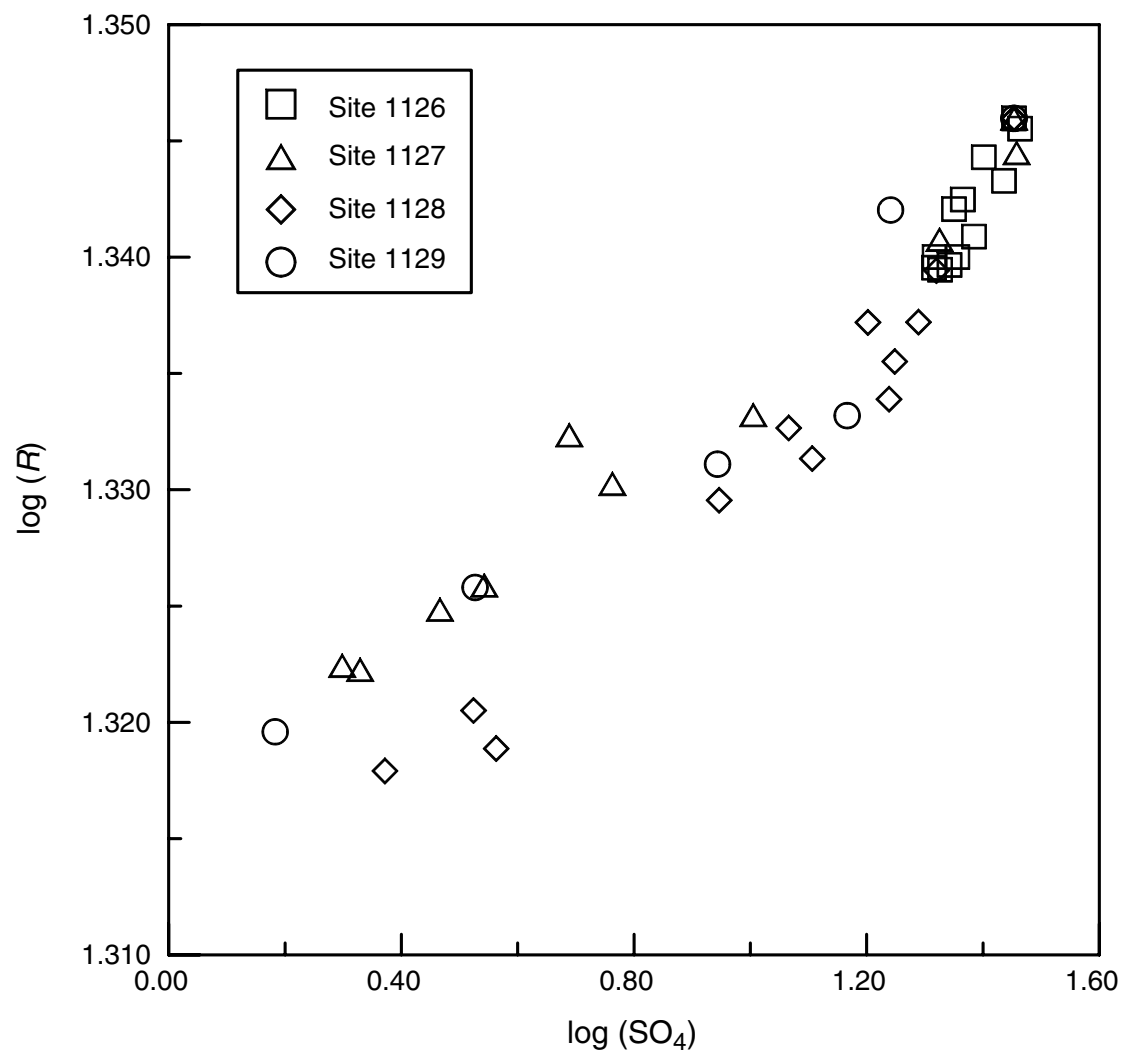


M.E. BötTChER ET AL.

SULFUR ISOTOPE FRACTIONATION

Figure F4. Sulfate concentrations vs. sulfur isotopic composition for all measured pore water sulfate samples from the Leg 201 sites compiled in Table T1, p. 19. The insert shows how different processes may influence the composition of dissolved sulfate. $1=$ bacterial sulfate reduction, $2=$ mixing with sulfate-rich deep brine. V-CDT = Vienna-Canyon Diablo troilite.

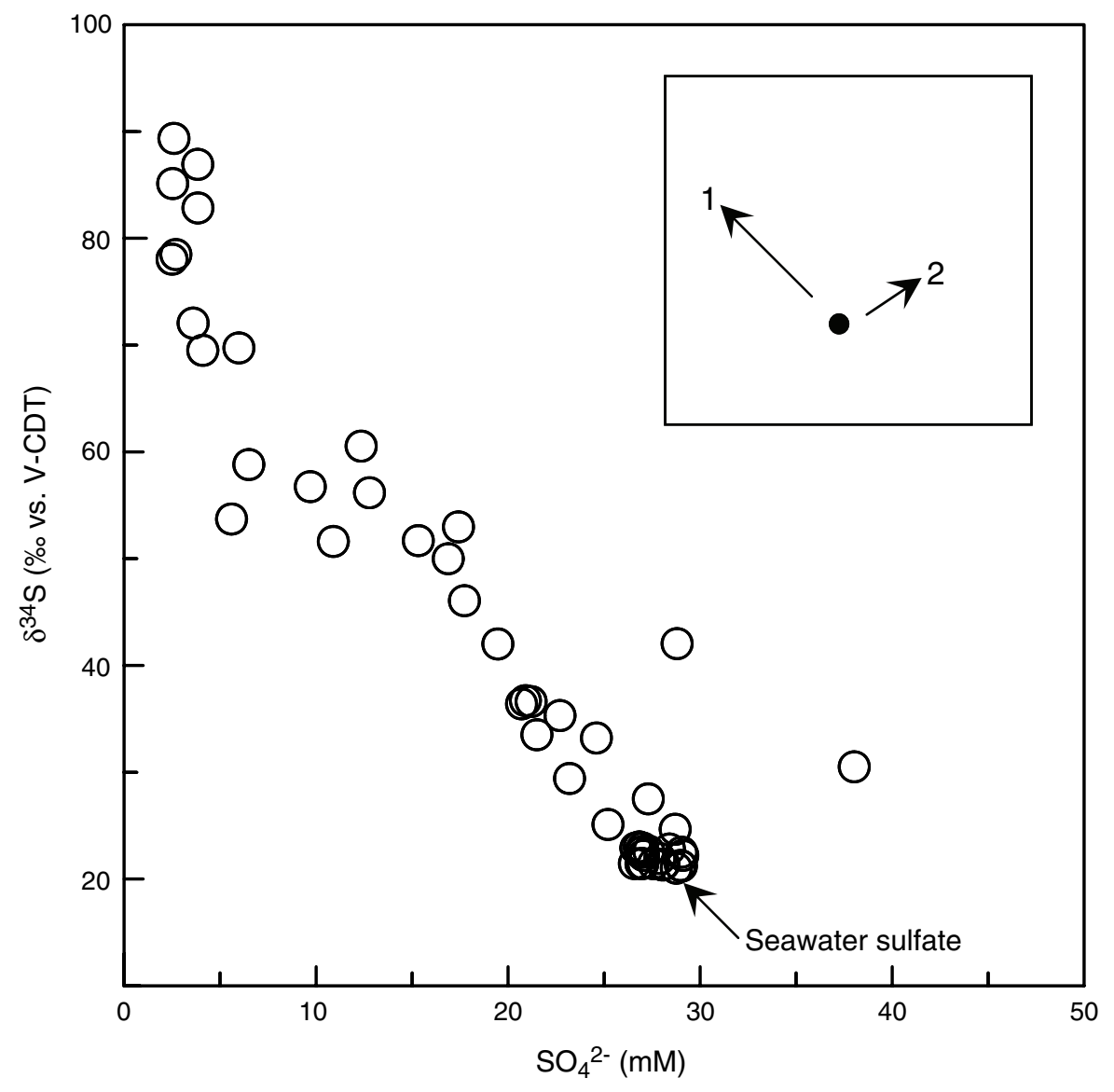


M.E. BÖTTCHER ET AL.

SULFUR ISOTOPE Fractionation

Table T1. Leg 201 sites.

\begin{tabular}{|c|c|c|c|c|c|c|c|c|}
\hline Site & PS & Description & $\begin{array}{c}\text { Water } \\
\text { depth (m) }\end{array}$ & Latitude & Longitude & $\begin{array}{c}\text { Temperature } \\
\text { range }\left({ }^{\circ} \mathrm{C}\right)\end{array}$ & $\begin{array}{c}\text { TOC } \\
\text { (wt\%) }\end{array}$ & $\begin{array}{l}\text { Sedimentation } \\
\text { rate }(\mathrm{m} / \mathrm{m} . \mathrm{y} .)\end{array}$ \\
\hline 1225 & 851 & Equatorial upwelling & 3760 & $2^{\circ} 46.22^{\prime} \mathrm{N}$ & $110^{\circ} 34.31^{\prime} \mathrm{W}$ & $1.4-7.0$ & $0-0.9$ & $10-68$ \\
\hline 1226 & 846 & Equatorial upwelling & 3297 & $3^{\circ} 05.70^{\prime} \mathrm{S}$ & $90^{\circ} 49.08^{\prime} \mathrm{W}$ & $1.7-24.4$ & $0-2$ & $10-50$ \\
\hline 1227 & 684 & Ocean margin; Peru shelf & 427 & $8^{\circ} 59.49^{\prime} \mathrm{S}$ & $79^{\circ} 54.35^{\prime} \mathrm{W}$ & $8.6-6.4$ & $0.6-10.6$ & $8-50$ \\
\hline 1228 & 680 & Ocean margin; Peru shelf & 252 & $11^{\circ} 03.90^{\prime} \mathrm{S}$ & $78^{\circ} 04.67^{\prime} \mathrm{W}$ & $12.5-19.3$ & $0.1-13$ & $22-55$ \\
\hline 1229 & 681 & Ocean margin; Peru shelf & 151 & $10^{\circ} 58.60^{\prime} \mathrm{S}$ & $77^{\circ} 57.46^{\prime} \mathrm{W}$ & $13.4-20.2$ & $0.8-4$ & 80 \\
\hline 1231 & 321 & Ocean margin; Peru Basin & 4827 & $12^{\circ} 01.29^{\prime} \mathrm{S}$ & $81^{\circ} 54.24^{\prime} \mathrm{W}$ & $1.7-8.6$ & $0-0.6$ & ND \\
\hline
\end{tabular}

Notes: PS = previous ODP/DSDP site drilled at essentially the same position as the Leg 201 site. TOC = total organic carbon. In situ temperature range between the sediment/water interface and the estimated base of drilled sediment column after D'Hondt, Jørgensen, Miller, et al. (2003). TOC data and sedimentation rates are taken from Cameron (1976), Suess, von Huene, et al. (1988), von Breymann et al. (1990), and D'Hondt, Jørgensen, Miller, et al. (2003). ND = not determined. 
M.E. BöTTCHER ET AL.

SULFUR ISOTOPE FRACTIONATION

Table T2. Sulfur isotope data for dissolved sulfate measured in Leg 201 pore water.

\begin{tabular}{|c|c|}
\hline $\begin{array}{l}\text { Core, section, } \\
\text { interval }(\mathrm{cm})\end{array}$ & $\begin{array}{c}\delta^{34} \mathrm{~S} \\
(\% \circ \mathrm{V}-\mathrm{CDT})\end{array}$ \\
\hline \multicolumn{2}{|l|}{ 201-1225A- } \\
\hline $1 \mathrm{H}-2,0-15$ & 21.0 \\
\hline $3 \mathrm{H}-2,135-150$ & 21.3 \\
\hline $4 \mathrm{H}-3,0-15$ & 21.3 \\
\hline $8 \mathrm{H}-3,0-15$ & 21.9 \\
\hline $10 \mathrm{H}-3,0-15$ & 22.2 \\
\hline $13 \mathrm{H}-3,135-150$ & 22.5 \\
\hline $14 \mathrm{H}-3,0-15$ & 22.5 \\
\hline $19 \mathrm{H}-3,135-150$ & 22.9 \\
\hline $20 \mathrm{H}-3,0-15$ & 22.8 \\
\hline $26 \mathrm{H}-3,0-15$ & 23.0 \\
\hline $30 \mathrm{H}-2,0-15$ & 22.9 \\
\hline $32 \mathrm{H}-3,0-15$ & 22.6 \\
\hline $33 \mathrm{H}-3,135-150$ & 22.5 \\
\hline \multicolumn{2}{|l|}{ 201-1226B- } \\
\hline $1 \mathrm{H}-3,0-20$ & 22.2 \\
\hline $3 \mathrm{H}-5,130-150$ & 27.5 \\
\hline $7 \mathrm{H}-2,130-150$ & 33.2 \\
\hline $11 \mathrm{H}-2,130-150$ & 35.3 \\
\hline $14 \mathrm{H}-2,130-150$ & 36.1 \\
\hline $16 \mathrm{H}-2,130-150$ & 36.4 \\
\hline $20 \mathrm{H}-2,130-150$ & 36.6 \\
\hline $24 \mathrm{H}-2,130-150$ & 36.4 \\
\hline $28 \mathrm{H}-2,130-150$ & 35.3 \\
\hline $38 \mathrm{X}-2,110-150$ & 30.4 \\
\hline $43 X-4,110-150$ & 29.4 \\
\hline $47 X-1,130-150$ & 25.1 \\
\hline \multicolumn{2}{|l|}{ 201-1227A- } \\
\hline $1 \mathrm{H}-2,135-150$ & 33.5 \\
\hline $2 \mathrm{H}-2,135-150$ & 51.6 \\
\hline $2 \mathrm{H}-5,135-150$ & 58.8 \\
\hline $3 \mathrm{H}-1,135-150$ & 53.7 \\
\hline $3 \mathrm{H}-3,135-150$ & 69.5 \\
\hline $3 \mathrm{H}-5,135-150$ & 72.1 \\
\hline
\end{tabular}

\begin{tabular}{|c|c|}
\hline $\begin{array}{l}\text { Core, section, } \\
\text { interval }(\mathrm{cm})\end{array}$ & $\begin{array}{c}\delta^{34} \mathrm{~S} \\
(\% \circ \mathrm{V}-\mathrm{CDT})\end{array}$ \\
\hline \multicolumn{2}{|l|}{ 201-1227D- } \\
\hline $1 \mathrm{H}-1,0-1$ & 24.7 \\
\hline $4 \mathrm{H}-2,135-150$ & 78.5 \\
\hline $4 \mathrm{H}-4,135-150$ & 78 \\
\hline \multicolumn{2}{|l|}{ 201-1228A- } \\
\hline $1 \mathrm{H}-2,135-150$ & 50 \\
\hline $2 \mathrm{H}-5,135-150$ & 56.2 \\
\hline $4 \mathrm{H}-3,135-150$ & 86.9 \\
\hline $5 \mathrm{H}-4,135-150$ & 89.4 \\
\hline $7 \mathrm{H}-1,135-150$ & 82.8 \\
\hline $11 \mathrm{H}-1,85-100$ & 60.5 \\
\hline $14 \mathrm{H}-3,135-150$ & 53 \\
\hline $21 \mathrm{H}-1,135-150$ & 42 \\
\hline \multicolumn{2}{|l|}{ 201-1228C- } \\
\hline $1 \mathrm{H}-1,30-45$ & 36.7 \\
\hline $1 \mathrm{H}-1,60-75$ & 42 \\
\hline $1 \mathrm{H}-1,90-105$ & 46.1 \\
\hline \multicolumn{2}{|l|}{ 201-1229A- } \\
\hline $1 \mathrm{H}-3,131-148$ & 51.7 \\
\hline $3 \mathrm{H}-1,135-150$ & 56.7 \\
\hline $11 \mathrm{H}-6,135-150$ & 85.1 \\
\hline $13 \mathrm{H}-3,135-150$ & 69.7 \\
\hline $22 \mathrm{H}-1,135-150$ & 30.5 \\
\hline \multicolumn{2}{|l|}{ 201-1231B- } \\
\hline $2 \mathrm{H}-5,135-150$ & 21.2 \\
\hline $4 \mathrm{H}-3,135-150$ & 21.4 \\
\hline $7 \mathrm{H}-3,135-150$ & 21.4 \\
\hline $9 \mathrm{H}-3,135-150$ & 21.4 \\
\hline $11 \mathrm{H}-3,135-150$ & 21.4 \\
\hline $13 \mathrm{H}-2,135-150$ & 21.4 \\
\hline
\end{tabular}

Note: V-CDT = Vienna-Canyon Diablo troilite. 
M.E. BöTtCHER ET AL.

SULFUR ISOTOPE FRACTIONATION

Table T3. Rayleigh sulfur isotope fractionation factor.

\begin{tabular}{|c|c|c|c|c|}
\hline Site & $\begin{array}{c}\text { Water } \\
\text { depth }(m)\end{array}$ & $\alpha_{R}$ & $J_{d} /\left(J_{d}+J_{b}\right)$ & $\begin{array}{c}\mathrm{SRR} \\
\left(\mathrm{mmol} / \mathrm{m}^{2} / \mathrm{yr}\right)\end{array}$ \\
\hline \multicolumn{5}{|l|}{ Leg 201} \\
\hline 1225 & 3760 & 1.014 & 0.82 & ND \\
\hline 1226 & 3297 & 1.040 & 0.46 & 14 \\
\hline 1227 & 427 & 1.019 & 0.75 & 82 \\
\hline 1228 & 252 & 1.023 & 0.67 & 573 \\
\hline 1229 & 151 & 1.018 & 0.59 & 681 \\
\hline \multicolumn{5}{|l|}{ Leg 181} \\
\hline 1119 & 396 & 1.015 & 0.80 & ND \\
\hline 1120 & 544 & 1.029 & 0.61 & ND \\
\hline 1121 & 4490 & 1.009 & 0.88 & ND \\
\hline 1122 & 4432 & 1.048 & 0.36 & ND \\
\hline 1123 & 3290 & 1.045 & 0.40 & ND \\
\hline 1124 & 3978 & 1.040 & 0.47 & ND \\
\hline 1125 & 1350 & 1.014 & 0.81 & ND \\
\hline
\end{tabular}

Notes: $\alpha_{R}=$ minimum isotope fractionation under apparent closed system, conditions calculated based on pore water sulfate profiles in the upper sulfate zone (see text). Estimated $\alpha_{R}$ values for the deep (brine influenced) sulfate zone were found to be 1.028 (Site 1228) and 1.022 (Site 1229). Openness of the sedimentary system toward dissolved sulfate $\left(J_{d} /\left[J_{d}+J_{b}\right]\right)$ are calculated based on the relationship derived by Claypool (2004; see text). SRR = depth integrated sulfate reduction rates, measured with radiotracers in the whole sulfate zone (J. Kallmeyer and T.G. Ferdelman, pers. comm., 2004). Results are compared to sites from the southwest Pacific (ODP Leg 181; Böttcher et al., 2004b). $\mathrm{ND}=$ not determined. 